\title{
The Swiss Public Opinion Towards the Tasks of the Swiss Armed Forces and the Constitutional Role
}

\author{
Thomas Fersta, Tibor Szvircsev Tresch ${ }^{\mathrm{a}}$
}

\begin{abstract}
After the Cold War, all European armed forces have transformed to be prepared for the new geopolitical environment and have taken new tasks. Since then, the European armed forces are more active in international conflict management. Whereas most of the European states have suspended the conscription, the Swiss Armed Forces still hold on conscription. However, the Swiss Armed Forces have changed also. The reform "Armee 95" in 1995 and the reform "Armee XXI" in 2004 have transformed the Swiss Armed Forces and extended their range of tasks. Which of these tasks are legitimated by the Swiss population? To answer this question, the Swiss population had been interviewed about the tasks of the Swiss Armed Forces as part of the study "Sicherheit 2016". The tasks which the Swiss population mentioned are displayed in this paper with regard to the transformation process classified and discussed. The evaluation shows that 93\% of the interviewees have named one of Switzerland's constitutional duties (defense, support of the civilian authorities, and promotion of peace within an international context) as the most important task of the Swiss Armed Forces. Mainly the national defense order and the subsidiary support of the civilian authorities are approved by the Swiss population.
\end{abstract}

\section{Keywords}

Swiss Armed Forces, transformation of European armed forces, conscription, militia, study “Sicherheit 2016"

After the end of the Cold War in 1990, the armed forces in Western and Eastern Europe were transformed. Since then, besides the classical national defense, they have exercised additional tasks like international peacekeeping operations and national support operations in a larger mass. These changes can be classified into three typologies. Whereas the first period (1990-1995) was characterized by cost-related reduction of the armed forces, it brought the second period (1996-2000/2001) an increasing level of NATO-orientated professionalization and internalization. Since $2000 / 2001$, the reforms of the armed forces have been affected by modularization and flexibility (Haltiner and Klein 2002).
Due to the changing security-political environment, many European armed forces suspended conscription for the benefit of a volunteer service (Werkner 2006; Szvircsev Tresch 2005; Werkner 2004; Haltiner 2003; Manigart 2002; Soeters and Bos-Bax 2002; Battistelli 2000). While the classical national defense got in the background, the focus changed towards a global, security-political based orientation. Through the increased use of European armed forces, considering

\footnotetext{
aSwiss Military Academy at the ETH Zurich, Switzerland

Correspondent Author:

Thomas Ferst, Caserne, 8903 Birmensdorf, Switzerland
} 
international crisis and conflicts, the armed forces had to take over new tasks. Furthermore, due to the increasing international involvement, more professional structures were needed. Compulsory military services like the Swiss Armed Forces are suitable to only a limited extend of international missions, because only volunteers, professionals, and non-career soldiers can be sent to serve abroad. Availability, operational capability, and mobility are the new and essential criteria of the military efficiency (Haltiner and Kümmel 2008).

Switzerland is in the European comparison due to its neutrality and the fact that it is neither an NATO nor an EU member, a special case, but it is still affected by the geostrategic and international change. Therefore, the question arises how these changes affect the acceptance of the Swiss Armed Forces and their tasks. The Swiss population supported the Swiss Armed Forces strongly in 2016. The results of the study "Sicherheit 2016" show clearly that the trust in the armed forces increased significantly and the acceptance for the need of the armed forces is with $84 \%$ above the average. The $46 \%$ of the Swiss population state that the armed forces play a central role in their life; $57 \%$ support the militia system clearly and just about one third (34\%) tend to suspend conscription. The population is satisfied with the performance of the Swiss Armed Forces (Szvircsev Tresch et al. 2016).

Due to the transformation process, the tasks of the Swiss Armed Forces have changed as well. It is not only interesting that the Swiss Armed Forces are widely accepted by the population as shown above, but also how the Swiss population thinks about the tasks of the Swiss Armed Forces. Therefore, the following questions arose as part of this paper:

Which tasks of the Swiss Armed Forces should be called upon to fulfill and how far are the tasks written in the constitution align with the ones the Swiss population sees?

To answer these research questions, an open question concerning the tasks of the armed forces had been asked in the study "Sicherheit 2016".

In the first step, the change in the military organizations and the assignment of tasks of European armed forces are described. Furthermore, there is an extra section discussing Switzerland as a special case. Subsequently, the methodical basis of the study "Sicherheit 2016" is explained and the results from the research question are presented. In the last chapter, the results are placed in relation to the transformation process of the Swiss Armed Forces.

\section{THEORETICAL EMBEDDING}

In the following chapter, the change of the military organizations and the key factors of the transformation are presented. The section after illustrates the special situation of the Swiss Armed Forces.

\section{The Change of the European Military Organizations}

There are different reasons for the end of the armed forces based on conscription in Europe. As an explanation, there are the technical changes and the continuing industrialization after the Second World War as well as the socio-political factors and the change in values in Europe (Szvircsev Tresch 2005).

Szvircsev Tresch (2015) underlined that in particular the changes in the geostrategic environment are the main reason for the suspension of conscription in Europe. After the Cold War, the defense policy had to be adjusted to the new challenges, specially "out of area missions" as part of the UN or NATO. In the course of this, many European armed forces became more professional and suspended conscription. In 1990, 22 of 26 European states had an armed force based on conscription and four states had an all-volunteer force (Great Britain, Ireland, Luxemburg, and Malta). In 2014, 27 out of 39 European states have suspended conscription (Szvircsev Tresch 2015). 


\section{Four Key Factors Responsible for the Transformation of the Armed Forces}

As previously mentioned, the changes of the military organizations can be influenced by social, technological, economic, and geostrategic factors. Due to these factors, European armed forces underwent three different waves of reform that are closely linked to the suspension of conscription (Haltiner and Klein 2002; Haltiner and Szvircsev Tresch 2005).

(1) The Downsizing Wave (1990-1995):

The first wave of reform was predominantly a cost-motivated downsizing of the armed forces including a reduction of the period of service. The primary goal was to reduce costs through cutbacks in personnel, weapons, and equipment (Haltiner and Klein 2002; Haltiner and Szvircsev Tresch 2005).

(2) The Mission Redefinition Wave (1995-2000):

The second wave was mainly provoked and accelerated by UN and NATO interventions in the Balkans in 1991. All over Europe, large multinational military brigades were introduced (Haltiner and Klein 2002; Haltiner and Szvircsev Tresch 2005).

(3) The Structural Reform Wave (2000-2010):

The third wave of reform aimed at a comprehensive structural modularization, flexibility, and professionalization of the armed forces. Reaction times were reduced and a higher degree of stand-by readiness was required. Therefore, an increase in availability of short-term personnel for out-of-area-operations was needed. As a consequence, the conscription lost its function altogether (Haltiner and Klein 2002; Haltiner and Szvircsev Tresch 2005).

Social factors. Well before the end of the Cold War, the social structure of societies was changing and in fact the conscription-based system was already criticized at that time in Europe and the US. This change in values had a significant influence on the armed forces in Europe. Traditional values have become less significant and values such as autonomy and self-determination become more important. The military organizations lost their acceptance and legitimacy in society (Van Doorn 1975; Feld 1975; Friedman 1967; Janowitz 1972; Manigart 1990).

Technological factors. By using modern military technology, armed forces become more efficient while employing less staff. The technological progress has two consequences: On the one hand, there is an increasing need for well-trained staff with higher education qualifications. On the other hand, less specialized activities are diminishing due to automation or outsourcing. This leads to a reduction of staff in the armed forces. Armed forces also have to be deployable in the areas of low-intensity conflicts and the fight against terrorism. Therefore, the image of a soldier is changing. He is no longer seen as a fighter only, he also needs managerial and technical skills (Haltiner and Klein 2004; Szvircsev Tresch 2015).

Economic factors. Due to the globalization and the cost-benefit analysis of public service institutions, economic aspects become politically important for the transformation from conscription-based armed forces to all-volunteer forces. In many European armed forces, the change to all-volunteer forces was budget-driven. Compared to the 1990s, most NATO and European states spend a lower percentage of their money on their armed forces. However, the supposed peace dividend is ambivalent because of increased fights against terrorism and raising defense spending (Kerstens and Meyermans 1993; Richter and Schleicher 1996; Friedman 1967; Hahn 1999; Jackwerth 1998; McNown, Udis, and Ash 1980).

Geostrategic factors. Since the demise of the Soviet Union on December 26, 1991, the risk of interstate wars in Europe has been reduced. However, the end of the bipolar constellation has led to a multiplication of new and complex risks and dangers. These threats can only be partly managed with conscription-based armed forces (Szvircsev Tresch 2015). Since 1989, low-intensity conflicts have become significantly more important. The focus of 
armed forces is shifting more and more away from national defense and mutual deterrence. Nowadays, the main task is crisis and conflict prevention, which requires the ability to deploy armed forces worldwide (Haltiner and Klein 2002). As a consequence, the number of military operations that can be qualified as non-traditional armed forces tasks has clearly increased (Siegrist 2008). Conscription-based armed forces are rather unsuitable for such international missions (Haltiner and Kümmel 2008).

\section{Switzerland: New Framework, New Tasks}

Due to the changing potential dangers, many European armed forces-including Switzerland - have begun to use their armed forces to support the police regarding the internal security. The Swiss Armed Forces support the Swiss Border Guard (SBG) by securing the borders, guarding foreign diplomatic representations, and strengthening the police in large-scale occasions of all kinds. Furthermore, it monitors the Swiss airspace as an air police. The separation between the internal security as a traditional task of the police and the external security as a traditional task of the armed forces has become incomplete because of the new threats. As a consequence, the police and the armed forces have to be adapted to the new domestic and supranational purposes. The armed forces support more and more the police and the police is getting militarized (Haltiner and Kümmel 2008; Haltiner 2004).

Since the establishment of the Swiss federal state in 1848, the Swiss Armed Forces have often been used for domestic tasks. Thereby, the protection of the neutrality through the armed forces had great importance $^{1}$. In Switzerland, the fight at the border was the most important task for an independent, neutral, and unoccupied state (Siegrist 2008).

The tasks of the Swiss Armed Forces are defined in the constitution. The political leadership places the orders to the armed forces within the constitutional framework. In Switzerland, no special purpose for the armed forces has to be defined, because the purpose of the armed forces is already given by the purpose of the state and by the existence of the Swiss Armed Forces. Since 1848, the Swiss Armed Forces have created an integration factor (Szvircsev Tresch 2011). The militia system united all social classes as well as the four language areas. Unlike other European states, Switzerland almost has not made any negative experiences with its armed forces. "The militia was not an antipode to the politics, but a part and a core of the politics" (Siegrist 2008: 50). The political culture, the military service, and the foreign affairs are connected (Siegrist 2008).

After 1989, the Swiss concept of "overall defense" (Gesamtverteidigung) has changed into the concept of "security policy" (Sicherheitspolitik). The Swiss Armed Forces have taken over tasks in the course of area protection and defense, as well as subsidiary operations to support civil authorities, if they are unable to provide the required resources by themselves. Moreover, the Swiss Armed Forces have become more active in promotion of peace within an international context. If the Swiss Armed Forces take over new tasks, the population often considers it primarily as an "improper task" (Siegrist 2008).

\section{Influence of the Political-Military Culture on the Military Structure Decisions}

The political-military culture in Europe was mainly influenced by the Second World War and the social change in 1989/1990 in connection with the end of the East-West conflict. The comparison between Belgium, Germany, Denmark, France, Netherlands, Spain, Austria, and Switzerland clarifies the special case of Switzerland. In contradiction to the named states, Switzerland is following a strictly neutralistic-abstinent way. The good experience in the past with neutrality, the abstinence from international organizations, and a skeptical attitude against an institutional multilateralism are key elements of the Swiss political culture (Haltiner and Kümmel 2008). 
Through the end of the bipolar world, neutrality lost its original meaning. Nevertheless, neutrality is deep-rooted in the Swiss population ${ }^{2}$.

The task area of the armed forces has changed after 1989 in favor of international missions due to crisis and conflicts. This development contrasts the so far valid traditions in Switzerland. Switzerland has adjusted to this new constellation with two military reforms ("Armee 95" and "Armee XXI") and is now slightly active in international peacekeeping missions. Despite the new political orientation, Switzerland adheres to its neutrality, militia, and conscription (Szvircsev Tresch 2011).

\section{Transformation of the Swiss Armed Forces}

The Swiss Armed Forces have to develop periodically. The security situation has to be reassessed regularly through all parties of the national security cooperation. The Swiss Armed Forces must be able to fulfill both military and police tasks. Out of this, the constitution defines the tasks of the Swiss Armed Forces: war prevention, peacekeeping, supporting of the civil authorities in extraordinary situations, and defense of serious threats to internal security (Schweizer Eidgenossenschaft 2016a). The Swiss Military Act (Militärgesetz) regulates operations to support peace and conflict prevention abroad under UN or OSCE mandates (Schweizer Bundesrat 2016).

With the reforms "Armee 95" (1995-2003), "Armee XXI" (2003-2017), and the "Weiterentwicklung der Armee" (WEA, as from 2018), the transformation process has been implemented since 1995.

As a result of those three reforms, the size of the armed forces was successively reduced. Personnel, materials, and equipment decreased. Furthermore, the armed forces were aligned to the new threats and increased cooperations with foreign partners (Schweizer Eidgenossenschaft 2016b). As usual in armed forces transformations, social, technical, economic, and geostrategic factors were also considered in Switzerland.

Due to the fact that Switzerland captures on conscription, neutrality, militia, and its political culture, the Swiss Armed Forces are less active in the context of international missions compared to other European armed forces. How does the Swiss population estimate the international development and which armed forces tasks derive out of this?

\section{METHODS}

The study "Sicherheit 2016" serves as the empirical basis to answer the research question. The annual "Sicherheit" survey, jointly conducted by the Military Academy at ETH Zurich (Swiss Federal Institute of Technology Zurich) and the Center for Security Studies of ETH Zurich, serves to determine trends in the formation of opinion on foreign, security, and defense policy in Switzerland. It is based on representative surveys of the Swiss electorate, carried out on an annual basis (Szvircsev Tresch et al. 2016).

Apart from core questions which are always included, questions about current issues of security policy are annually included as well. In 2016, among others, particular attention was paid to the question, "Which tasks of the Swiss Armed Forces should be called upon to fulfill?". Therefore, there was an open question asked in the study "Sicherheit 2016" about this topic. The question was: "Which tasks of the Swiss Armed Forces should be called upon to fulfill in your opinion? Please tell us everything that is in your mind". Data collection took place via telephone with CATI (Computer Assisted Telephone Interview) between January 4 and January 23, 2016, with 1,211 people from all language regions of Switzerland (the German-speaking and French-speaking regions of Switzerland as well as the Italian-speaking region of Ticino).

The sample selection was based on the random-quota-method (age, gender, and region). An interview took in average 28 minutes. Different from 
earlier interviews, not only fixed line numbers, but also mobile numbers had been called for the study 2016. The idea was to include the changing user behavior in the communication area. In total, $12 \%$ of all interviews were held via a mobile number. The chapter results describe in detail the results of the open research question (Szvircsev Tresch et al. 2016).

\section{RESULTS 3}

The Swiss Armed Forces are in a process of transformation into an armed force with a wide range of tasks. The new orientation was shown in the concept "Armee XXI", which became effective in 2004, as well as in the discussion about the "Weiterentwicklung der Armee" in the last few years.
This discussion about the strategic and operative alignment makes clear that the meanings about the tasks of the armed forces are wide-ranging. Therefore, the open question "Which tasks of the Swiss Armed Forces should be called upon to fulfill in your opinion? Please tell us everything that is in your mind" was asked to determine the opinion of the Swiss population concerning the tasks, which the army should be called upon to fulfill.

From the 1,211 persons who have been questioned, 1,174 mentioned at least one task. Table 1 shows that in total 3,625 answers have been noted. Respondents gave in average three mentions. There are 1,174 answers for the first mention. The 1,034 persons gave a second mention. The number of answers decreases continuously.

Table 1. Number of Answers on the Open Question About the Tasks of the Swiss Armed Forces

\begin{tabular}{lllllllllll}
\hline Mention & First & Second & Third & Fourth & Fifth & Sixth & Seventh & Eighth & Ninth & Tenth \\
\hline $\begin{array}{l}\text { Number of answers } \\
\text { Total answers }\end{array}$ & 1,174 & 1,034 & 748 & 422 & 172 & 52 & 14 & 5 & 3 & 1 \\
\hline
\end{tabular}

The spontaneous answers were coded. The categorization from the study "Sicherheit 2006" (Haltiner et al. 2006), in which another open question about the tasks of the armed forces had been asked, was used as a reference. Based on this, two researchers compared the mentions independently and put them into a category system. Afterwards, these mentions were reviewed by a third person. Finally, the 3,625 spontaneous mentions were assigned in 28 different categories. The result was a category system like the one in Table 2 . The categories, the number of mentions (total: 3,625), and the percentages of all persons who gave at least one answer $(\mathrm{N}=1,174)$ per category, were included.

Table 2. Categorization of the Tasks of the Swiss Armed Forces (Szvircsev Tresch et al. 2016: 149)

\begin{tabular}{lll}
\hline Category & Number of mentions & Respondents (\%) (N =1,174) \\
\hline Disaster assistance (floods, fires, landslides, disasters) & 696 & 59 \\
National defense/country protection & 475 & 40 \\
Support of the police and blue-light organizations & 353 & 30 \\
Border guard, border protection & 330 & 28 \\
General security & 290 & 25 \\
Guard of embassies, conferences, events, and occasions & 260 & 22 \\
Civil protection & 131 & 11 \\
Help in Switzerland, presence in Switzerland (sport aid, mountain aid, & 130 & 11 \\
clean up forests) & 100 & 9 \\
Surveillance of airspace & 93 & 8 \\
Education & &
\end{tabular}


(Table 2 continued)

\begin{tabular}{lll}
\hline Category & Number of mentions & Respondents (\%) (N =1,174) \\
\hline Peace promotion/peacekeeping & 91 & 8 \\
Prevention of terrorist attacks & 86 & 7 \\
Operational readiness & 86 & 7 \\
Preservation of the independency, neutrality & 52 & 3 \\
Operations in crisis situation & 42 & 3 \\
Humanitarian aid & 41 & 3 \\
Operations for the internal arrangement & 40 & 3 \\
Civil protection & 37 & 2 \\
Militia & 27 & 2 \\
Discipline/behaviour & 22 & 1 \\
Civilian service & 16 & 1 \\
Cooperation with other armed forces/NATO & 12 & 1 \\
Prevention of organized crime & 11 & 1 \\
Cohesion of the society in Switzerland & 11 & 12 \\
Other tasks (mobilisation, spying, monitoring, control, & & \\
communication, cyber-protection, refugees, airport, & 144 & \\
intelligence service) & & \\
Further mentions & & 21 \\
As before/same tasks & 21 & 15 \\
We don't need an army & 13 & 305 \\
Deeper defense expenditures & 3,625 & \\
Total & & \\
\hline
\end{tabular}

An absolute majority of the respondents (59\%) named "disaster assistance" as task of the armed forces. "National defense" was mentioned by $40 \%$ of the Swiss population spontaneously. Three in ten people mentioned "support of the police and blue-light organizations" (30\%) and "border guard" (28\%). One quarter saw "general security" (25\%) and the "guard of embassies, conferences, events, and occasions" $(22 \%)$ as a task of the armed forces. One out of ten thought that the armed forces should fulfill tasks in the course of "civil protection" (11\%), "help in Switzerland" (11\%) as well as "surveillance of airspace" (9\%), "education" (8\%), and "peacekeeping" $(8 \%)$. Even "prevention of terrorist attacks" and "operational readiness" were respectively for $7 \%$ of the interviewed persons as important tasks for the armed forces. The other named categories were mentioned by less than $5 \%$ of the people. The answers of $12 \%$ of the interviewed persons were assigned to the category "other tasks" (see Table 2). Further mentions do not refer to the actual tasks, but demand that the armed forces have to be abolished and the defense spending has to be reduced or that only the same tasks as before should be fulfilled.

\section{DISCUSSION OF THE RESULTS}

Concerning the different mentions, two assumptions can be made:

(1) The different mentions of the tasks of the Swiss Armed Forces are connected with the tasks that the Swiss Armed Forces provided in 2015;

(2) The services provided by the Swiss Armed Forces are differently weighted in the media.

Table 3 shows the services provided by the Swiss Armed Forces in 2015. 
Table 3. Services of the Swiss Armed Forces 2015 (Schweizer Eidgenossenschaft 2015)

\begin{tabular}{ll}
\hline Area with the performed service & Supplied service days \\
\hline Fundamental mission (education, operational readiness) & $5,585,483$ \\
Subsidiary security services & 76,478 \\
Military disaster aid & 1,477 \\
Supporting services & 23,336 \\
Peace promotion services & 105,849 \\
Total of supplied service days & $5,792,623$ \\
\hline
\end{tabular}

Besides the fundamental missions, the performed services can be classified into subsidiary safety services [World Economic Forum (WEF) in Davos, protection of embassy], military disaster aid, supporting services (air transport of water, support of big events), and international peace promotion. The Swiss Armed Forces regularly inform the public towards the performed services. The media report differently about the performed military services. Peace promotion is not an essential topic in the media. Only the extension of mandates is mentioned. In general, the media coverage is focused on domestic services (WEF, military disaster aid, and support of big occasions). Peace promotion is probably mentioned less often as a task of the Swiss Armed Forces, because it is a smaller topic in the media. If the media really have such a strong influence can just be assumed, but not verified with the available data. In fact, in 2015, more service days have been supplied in peace promotion $(105,849$ service days $)$ than in subsidiary security services $(76,478$ service days), supporting services (23,336 service days), and military disaster aid (1,477 service days).

According to the constitution and the military law, the Swiss Armed Forces have three tasks: defense, support for civilian authorities, and promotion of peace within an international context (Schweizer Eidgenossenschaft 2016c). Which of these three tasks does the Swiss population prioritize?

To answer this question, the assumption is made that respondents give the highest importance to their first spontaneous naming. Thereby, 1,174 persons had given at least one naming. In Table 4 , the 28 categorized answers are divided into five groups. The first group includes tasks like "national defense", "general security", "border control", and "operational readiness" in the sense of defense capabilities. Furthermore, the task of the armed forces to preserve the Swiss independence and neutrality against other states is also contained in this group. This includes the "cooperation with other armies and the NATO". The second group contains tasks, which are in relation with the support of the civil authorities. Mentions in the context of peace promotion are in the third group. While the groups one to three are based on the constitutional tasks of the Swiss Armed Forces, the fourth group contains other tasks. The fifth group includes tasks, which cannot be categorized differently.

Table 4. Classification of the First Mentions in Five Groups Concerning the 28 Categories (Szvircsev Tresch et al. 2016: 154)

\begin{tabular}{llll}
\hline Group description & Categories of the respective group with number of mentions & $\begin{array}{l}\text { Number of } \\
\text { mentions }\end{array}$ & $\begin{array}{l}\text { Percentages } \\
(\%)\end{array}$ \\
\hline $\begin{array}{l}\text { Group 1 } \\
\begin{array}{l}\text { Defense } \\
\text { (sovereign government tasks) }\end{array}\end{array}$ & $\begin{array}{l}\text { National defense/country protection (324), general security } \\
\text { (168), Border guard, border protection (109), airspace (25), } \\
\text { operational readiness (19), preservation of the independency, } \\
\text { neutrality (14), cooperation with other armies/NAT0 (2) }\end{array}$ & 56 \\
\hline
\end{tabular}


(Table 4 continued)

\begin{tabular}{|c|c|c|c|}
\hline Group description & Categories of the respective group with number of mentions & $\begin{array}{l}\text { Number of } \\
\text { mentions }\end{array}$ & $\begin{array}{l}\text { Percentages } \\
(\%)\end{array}$ \\
\hline $\begin{array}{l}\text { Group } 2 \\
\text { Support of civil authorities }\end{array}$ & $\begin{array}{l}\text { Disaster assistance (203), support of the police and blue-light } \\
\text { organizations (65), civil protection (50), guard of embassies, } \\
\text { conferences, events, and occasions (32), help in Switzerland, } \\
\text { presence in Switzerland (29), prevention of terrorist attacks } \\
(9) \text {, civil defense (9), use for the internal arrangement (6), use } \\
\text { in crisis situation (5), civilian service (4), prevention of } \\
\text { organised crime (1) }\end{array}$ & 413 & 35 \\
\hline $\begin{array}{l}\text { Group } 3 \\
\text { Peace promotion }\end{array}$ & Peace promotion/peacekeeping (12), humanitarian aid (7) & 19 & 2 \\
\hline $\begin{array}{l}\text { Group } 4 \\
\text { Other tasks }\end{array}$ & $\begin{array}{l}\text { Other tasks (21), education (17), militia (6), discipline/conduct } \\
(6), \text { cohesion of the society in Switzerland (1) }\end{array}$ & 51 & 4 \\
\hline $\begin{array}{l}\text { Group } 5 \\
\text { Not possible to categorize }\end{array}$ & $\begin{array}{l}\text { As before/same tasks (12), we don't need an army (12), } \\
\text { deeper defense tasks (6) }\end{array}$ & 30 & 3 \\
\hline Total & & 1,174 & 100 \\
\hline
\end{tabular}

With the focus on first mentions, the importance of the different tasks has changed. National defense is the most mentioned (324 mentions), followed by the disaster assistance (203 mentions). After the categorization into the five groups "defense", "support of civil authorities", "peace promotion", "other tasks", and "not possible to categorize", the following picture is shown: The majority of $56 \%$ of the Swiss population mentioned as the first naming a task belonging to the actual national defense. The $35 \%$ of the questioned persons mentioned the support of the civil authorities. Defense and support of civil authorities were definitely seen as the main tasks of the Swiss Armed Forces. The third constitutional task, peace promotion, was only mentioned by $2 \%$ of the Swiss population. The $4 \%$ of the Swiss population primarily mentioned other tasks and $3 \%$ of the first mentions could not be categorized, because the answers did not cover the same topic as any of the other four groups.

The variation according to socio-demographic characteristics for the three official armed forces tasks is differentiated ${ }^{4}$. There are no significant differences in the prioritization of the armed forces tasks related to the education, gender, and origin ${ }^{5}$, but there are significant differences related to the age and political orientation. People between 18 and 29 mentioned in the first place significantly more often the support of civil authorities compared to the other two age categories (30-59-year old, from 60-year old: $\gamma=.21$ ). People from 60 years old consider more often the average defense as a major task. The political left-wing respondents see the support of the civil authorities more often as a major task, while the political right-wing group rather prioritizes the national defense $(\gamma=.13)$.

\section{CONCLUSIONS}

The transformation of the Swiss Armed Forces was implemented with the reform projects "Armee 95", "Armee XXI", and "Weiterentwicklung der Armee". Thereby, the Swiss Armed Forces have been reduced, reoriented, and structurally reformed. Social, technological, economic, and geostrategic factors have been taken into account by the reforms. The new orientation of the Swiss Armed Forces includes the typical Swiss political-military culture. Neutrality as well as conscription was maintained, while participations in international missions have increased. Switzerland is and remains a special case concerning military political aspects. The currently very military friendly attitude of the Swiss voting population indicates a high legitimacy to this last transformation.

While the survey results about the necessity of the armed forces in 1990 (61\%, end of the Cold War), 
1996 (63\%, implementation of the "Armee 95"), and 2004 (59\%, implementation of the "Armee XXI") were below the average, the approval reached in 2016 with $84 \%$, the second highest value ever (Szvircsev Tresch et al. 2016). There is also no loss in trust and legitimation. The militia system as well as the conscription is supported by a majority of the Swiss population (Szvircsev Tresch et al. 2016). The open research question shows that the Swiss population considers different tasks for the Swiss Armed Forces. Concerning all 3,625 answers, disaster assistance, followed by national defense and support of the police and blue-light organizations, got the most support. In the evaluation of the first mentions, $93 \%$ of the Swiss population named one of the three statutory armed forces tasks. The $56 \%$ named national defense as the most important task. The authors assume that the idea of neutrality and the political-military culture strongly influenced the Swiss population. With 35\%, the Swiss population mentions the support of civil authorities as second most important task.

The support of the civil authorities through the Swiss Armed Forces is deeply anchored in both the constitution and the minds of the population. Each year, the Swiss Armed Forces support major events of national and international interest, assist in natural disasters, and secure the monitoring of the Swiss airspace.

Despite the fact that the Swiss Armed Forces supplied more service days in peace promotion than in subsidiary security services, support services, and military disaster assistance, only $2 \%$ of the Swiss population mentioned peace promotion as the most important task of the Swiss Armed Forces. The authors assume that due to the small media discourse about peace promotion, the public perception about this task is low. Furthermore, only volunteers provide peace promotion services. The Swiss population defines their armed forces strongly on conscription, militia system, and neutrality. The question asked at the beginning can be answered that two of the constitutional tasks (defense and support of the civil authorities) are strongly legitimated by the population, but the third constitutional task is less present in the mind of the Swiss population.

\section{Notes}

1. Safeguarding neutrality includes border guard, border police, airspace control, and air police (Siegrist 2008).

2. The results of the study "Sicherheit 2016" show that the Swiss practically unanimously support the neutrality (95\%). The $85 \%$ think that the neutrality is inseparably linked with the view of the state (Szvircsev Tresch et al. 2016).

3. This part is slightly adapted from the printed version of the study "Sicherheit 2016" (Szvircsev Tresch et al. 2016: 147-156).

4. With the following calculations, only the three groups "defense", "support of civil authorities", and "peace promotion" were considered.

5. The regional origin refers to the three language groups: German-, French-, and Italian-speaking regions.

\section{References}

Battistelli, F. 2000. "The Postmodern Military: Conscription or Professionalism?" Pp. 47-69 in Democratic Societies and Their Armed Forces. Israel in Comparative Context, edited by S. A. Cohen. London and Portland: Frank Cass.

Feld, M. D. 1975. "Military Professionalism and the Mass Army." Armed Forces \& Society 1(2):191-214.

Friedman, M. 1967. "Why Not a Voluntary Army?" Pp. 200-207 in The Draft. A Handbook of Facts and Alternatives, edited by S. Tax. Chicago and London: The University of Chicago Press.

Hahn, O. 1999. "Ökonomische Aspekte der Wehrstrukturmodelle" (Economic Factors of Defense Structure Models). Pp. 79-89 in Wehrhafte Demokratie 2000. Zu Wehrpflicht und Wehrstruktur (Defensive Democracy 2000. Conscription and Defense Structure), edited by A. A. Steinkamm and D. Schössler. Baden-Baden: Nomos Verlagsgesellschaft.

Haltiner, K. W. 2003. "The Decline of the European Mass Armies." Pp. 361-384 in Handbook of the Sociology of the Military, edited by G. Caforio. New York: Kluwer Academic/Plenum Publishers.

—. 2004. "Vom Landesverteidiger zum militärischen Ordnungshüter" (From a National Defender to a Military Law Enforcement Officier). Pp. 476-484 in Handbuch Militär und Sozialwissenschaft (Manual of Military and 
Social Science), edited by S. B. Gareis and P. Klein. Wiesbaden: VS Verlag für Sozialwissenschaft.

Haltiner, K. W. and G. Kümmel, eds. 2008. Wozu Armeen? Europas Streitkräfte vor neuen Aufgaben (Wherefore Armed Forces? European Armed Forces and New Tasks). Baden-Baden: Nomos Verlagsgesellschaft.

Haltiner, K. W. and P. Klein, eds. 2002. Europas Armeen im Umbruch (European Armed Forces in Transition). Baden-Baden: Nomos Verlagsgesellschaft.

—. 2004. Multinationalität als Herausforderung für die Streitkräfte (Multinationality as a Challenge for Armed Focres). Baden-Baden: Nomos Verlagsgesellschaft.

Haltiner, K. W. and T. Szvircsev Tresch. 2005. "The Decline of Conscription in Europe." Pp. 285-301 in Sodobno Vojaštvo in Družba. Fakultetazadružbenevede (Modern Warfare and Society. Faculty of Social Sciences), edited by A. Bebler. Ljubljana: Knjižnazbirka Varnostneštudije.

Haltiner, K. W., A. Wenger, T. Szvircsev Tresch, and S. Würmli. 2006. Sicherheit 2006, Aussen-, Sicherheits- und Verteidigungspolitische Meinungsbild im Trend (Security 2006, Trends in Public Opinion on Foreign Affairs, National Security and Defense Strategy). Zürich und Birmensdorf: Center for Security Studies, ETH Zürich und Militärakademie an der ETH Zürich.

Jackwerth, C. 1998. "Ökonomische Aspekte eines Vergleiches unterschiedlicher Wehrsysteme" (Economic Aspects of a Comparison of Different Defense Systems). Österreichische Militärische Zeitschrift, OEMZ (Austrian Military Journal) 36(4):375-382.

Janowitz, M. 1972. "The Decline of the Mass Army." Military Review 52:10-16.

Kerstens, K. and E. Meyermans. 1993. "The Draft Versus an All-Volunteer Force: Issues of Efficiency and Equity in the Belgian Draft.” Defence Economics 4:271-284.

Manigart, P. 1990. "The Decline of the Mass Armed Force in Belgium, 1900-1985." Pp. 37-64 in Problems and Options of the Mass Armed Forces. Forum International, Band 9 , edited by J. Kuhlmann. München: Sozialwissenschaftliches Institut der Bundeswehr.

- 2002. "The Professionalization of the Belgian Armed Forces." Pp. 115-131 in Comparative Analysis of Manning the Armed Forces in Europe, edited by M. Malešič. Ljubljana: University of Ljubljana, Obramboslovniraziskovalni Center.

McNown, R. F., B. Udis, and C. Ash. 1980. "Economic Analysis of the All-Volunteer Force." Armed Forces \& Society 7(1):113-132.

Richter, M. and M. Schleicher. 1996. "Von der Wehrpflicht zur Berufsarmee: Das Beispiel Belgien" (From Conscription to a Professional Army: Belgium as Example). Pp. 81-101 in Wehrpflicht oder Berufsarmee. Beiträge zur Debatte aus ökonomischer Sicht (Conscription or Professional Armed Forces. An Economic View), edited by T. Straubhaar and M. Schleicher. Bern: Haupt Verlag.

Schweizer Bundesrat. 2016. Bundesgesetz über die Armee und die Militärverwaltung (MG) (Federal Law of the Armed Forces and Military Administration). Retrieved June 19, 2016 (http://www.admin.ch/opc/de/classified-compilation/ 19950010/index.html).

Schweizer Eidgenossenschaft. 2015. Jahresbericht Schweizer Armee 2015 (Annual Report of Swiss Armed Forces 2015). Retrieved (http://www.vtg.admin.ch/de/organisation/heer/in fbr5.detail.publication.html/vtg-internet/de/publications/ver waltung/organisation/astab/81_129_dfi_Jahresbericht_der_ Schweizer_Armee_2015.pdf.html).

—. 2016a. Bundesverfassung der Schweizerischen Eigenossenschaft (BV), Art. 58 BV [Federal Constitution of the Swiss Confederation (BV), Article 58 BVJ. Retrieved June 19, 2016 (http://www.admin.ch/opc/de/classified-comp ilation/19995395/index.html).

- 2016b. Weiterentwicklung der Armee (WEA) (Development of the Armed Forces). Retrieved June 19, 2016 (http://www.vbs.admin.ch/internet/vbs/de/home/the men/defence/wea/uebersicht.html).

_. 2016c. Die Aufgaben der Armee (The Tasks of the Swiss Armed Forces). Retrieved June 19, 2016 (http://www.vtg. admin.ch/internet/vtg/de/home/themen/auftraege.html).

Siegrist, U. 2008. "Neue Rahmenbedingungen, neue Aufgaben" (New Framework, New Tasks). Pp. 45-56 in Wozu Armeen? Europas Streitkräfte vor neuen Aufgaben (Wherefore Armed Forces? European Armed Forces and New Tasks), edited by K. W. Haltiner and G. Kümmel. Baden-Baden: Nomos Verlagsgesellschaft.

Soeters, J. and M. Bos-Bax. 2002. "The Professionalisation of the Dutch Armed Forces." Pp. 67-81 in Comparative Analysis of Manning the Armed Forces in Europe, edited by M. Malešič. Ljubljana: University of Ljubljana, Obramboslovniraziskovalni Center.

Szvircsev Tresch, T. 2005. "Europas Streitkräfte im Wandel: Von der Wehrpflichtarmee zur Freiwilligenstreitkraft. Eine empirische Untersuchung europäischer Streitkräfte 1975 bis 2003" (Change of the European Armed Forces: From the Military Service to the Volunteer Armed Forces. An Empirical Study of European Forces From 1975 to 2003). Dissertation, Universität Zürich, Zürich.

- 2011. "The Transformation of Switzerland's Militia Armed Forces and the Role of the Citizen in Uniform." Armed Forces \& Society 37(2):239-260.

- 2015. "Europe's Armed Forces in Transition: From Conscription to All-Volunteer Forces, 1975-2014." Nemzetés Biztonsag (National Security) (Special Issue):6-18. 
Szvircsev Tresch, T., A. Wenger, T. Ferst, T. Graf, S. Pfister, and A. Rinaldo. 2016. Sicherheit 2016, Aussen-, Sicherheits- und Verteidigungspolitische Meinungsbild im Trend (Security 2016, Trends in Public Opinion on Foreign Affairs, National Security and Defense Strategy). Zürich und Birmensdorf: Center for Security Studies, ETH Zürich und Militärakademie an der ETH Zürich.

Van Doorn, J. 1975. "The Decline of the Mass Army in the West: General Reflections." Armed Forces \& Society 1(2):147-157.

Werkner, I.-J. 2004. "Wehrstrukturen im internationalen Vergleich" (Military Structures in an International Comparison). Pp. 89-100 in Handbuch Militär und Sozialwissenschaften (Manual of Military and Social Science), edited by S. B. Gareis and P. Klein. Wiesbaden: Verlag für Sozialwissenschaften.

- 2006. Wehrpflicht oder Freiwilligenarmee? Wehrstrukturentscheidungen im europäischen Vergleich
(Conscription or Volunteer Forces? An European Comparison of Decisions in Defense Structure). Frankfurt am Main: Peter Lang Verlag.

\section{Bios}

Thomas Ferst, lic. phil., MAS in Criminology (LL.M.), research project manager of series of study "Security", Department of Military Sociology, Swiss Military Academy at the ETH Zurich, Switzerland; research fields: public opnion, trends in public opinion on foreign affairs, national security and defense strategy.

Tibor Szvircsev Tresch, Ph.D., head for Department of Military Sociology, Swiss Military Academy at the ETH Zurich, Switzerland; research fields: change of the Swiss Armed Forces and militia, international development of armed forces, civil-military relations. 